\title{
Effect of NPK fertilization and elemental sulphur on growth and yield of lowbush blueberry
}

\section{Marge Starast}

University of Tartu, Institute of Botany and Ecology, Tartu, Estonia. Current address: Estonian University of Life Sciences, Institute of Agricultural and Environmental Sciences, Kreutzwaldi 64, 51014 Tartu, Estonia, e-mail:

marge.starast@emu.ee

Kadri Karp, Ele Vool

Estonian University of Life Sciences, Institute of Agricultural and Environmental Sciences, Kreutzwaldi 64,

51014 Tartu, Estonia

Taimi Paal

Estonian University of Life Sciences, Institute of Forestry and Rural Engineering, Kreutzwaldi 64,

51014 Tartu, Estonia

Tairi Albert

Estonian University of Life Sciences, Institute of Agricultural and Environmental Sciences

Kreutzwaldi 64, 51014 Tartu, Estonia

The aim of the research was to determine the effect of fertilizers on the $\mathrm{pH}$ of former arable soils and on the growth and the yield of the lowbush blueberry (Vaccinium angustifolium Ait.). Lowbush blueberry fertilization experiments were established in 1999 at two locations - at Kärla, Saaremaa, West Estonia and at Vasula, Tartu County, South Estonia. Experimental sites were situated on different soils: soil $\mathrm{pH}_{\mathrm{KCl}}$ at Kärla was 5.5 and at Vasula 6.2. Elemental sulphur and acidifying fertilizers (ammonium sulfate, potassium sulfate and superphosphate) were used in both plantations. Fertilizers were applied based on nutrient in the soil and sulphur was applied at $100 \mathrm{~g} \mathrm{~m}^{-2}$. Plant growth was recorded in 2001, 2002 and 2003. A positive influence of NPK fertilization on yield was found in both Kärla and Vasula, and yield were $336 \mathrm{~g}$ and 41 g higher compared to the control, respectively. The vegetative growth and yield of blueberry depended significantly on soil $\mathrm{pH}$. Elemental sulphur increased soil acidity and on loamy sand soil did not increase plant productivity. The sulphur effect on soil $\mathrm{pH}$ began to decrease three years after application. Sulphur can be recommended to increase soil acidity in nutrient-rich soil but, not nutrient poor soil with light texture, where only NPK fertilizers were effective.

Key-words: sulphur, fertilizers, soil pH, Vaccinium angustifolium, small fruits

(C) Agricultural and Food Science

Manuscript received November 2005 
Vol. 16 (2007): 34-45

\section{Introduction}

In Canada and the USA the lowbush blueberry is managed as a wild crop and it has a remarkable position in berry production. In Europe, where wild production of lowbush blueberries is not possible (this species is not natural in Europe), well-aerated sandy loams rich in humus are recommended for blueberry cultivation (Trehane 2004). It is important that the soil is acidic as blueberries are calcifuge plants. A major factor limiting blueberries to acid soils is considered to be their inability to efficiently utilize iron at high soil $\mathrm{pH}$ (Brown and Draper 1980). However, in the study carried out by Haynes and Swift (1986) the deficiency of magnesium rather than iron appeared to limit growth in soils with high soil $\mathrm{pH}$. In USA and Canada elemental sulphur is widely used to decrease soil $\mathrm{pH}$. Elemental sulphur applied once at a rate of $1120 \mathrm{~kg} \mathrm{ha}^{-1}$ reduced the $\mathrm{pH}$ value from 6.1 to 5.4 after two years (Spiers and Braswell 1992). The growth and yield of hybrid and highbush blueberry are significantly influenced by using mulches in cultivation (Clark and Moore 1991, Spiers 1998, Nesmith 2003). Haynes and Swift (1986) concluded that the addition of organic matter and an acidifying agent (sulphur) to the planting hole could greatly increase the early growth and yields of blueberries in mineral soil. In experiments carried out in Prince Edward Island soil $\mathrm{pH}$ was significantly reduced by gypsum, which increased blueberry yield with $225 \mathrm{~kg} \mathrm{ha}^{-1}$. (Sanderson et al. 1996). It was sufficient to cover the costs of the applied gypsum. Different mulches can also change the $\mathrm{pH}$ of soil. For example, peat moss and pine needle litter reduced $\mathrm{pH}$ value from 5.6 to 4.6 and 4.7, respectively (Gustavson 1999). There are also other possibilities to lower soil $\mathrm{pH}$. Soil $\mathrm{pH}$ has been reduced by using combined primary and secondary papermill sludge, which is a good potential source of carbon and other nutrients to restore a low level of organic matter in sandy soils supporting native lowbush blueberry (Gagnon et al. 2003).

Fertilization requirements of blueberries are smaller than other berry crops. In experiments carried out in Poland, the most severe frost damage of the bushes were observed on plots fertilized with
$150 \mathrm{~kg} \mathrm{~N} \mathrm{ha}^{-1}$ and the results obtained indicate that the optimal nitrogen dose for highbush blueberry is about 50-100 $\mathrm{kg} \mathrm{ha}^{-1}$ (Smolarz and Mercik 1989). In Norway, highbush blueberry production has many problems. These include a short growing season, poor snow cover, low winter temperatures and susceptibility to Godronia canker (Strømeng and Stensvand 2001). In North Europe, there is a great need for experiments with other hardy blueberry species like lowbush blueberry and its hybrids. Experimental results with lowbush blueberry in Canada might not be applicable in North Europe. The lowbush blueberry in Canada is native, but in Europe producers have established plantations with similar plants. Therefore, it is necessary to study the influence of fertilization on the soil and development of plants after establishing a plantation. As lowbush blueberry has been used for breeding several half highbush blueberry cultivars, it can be suggested that fertilization recommendations for half-highbush blueberry might also be suitable for lowbush blueberry. It is known that fertilizer can alter soil reaction, but fertilization needs of blueberries are very low. Therefore the question arises: Is it possible to change soil $\mathrm{pH}$ suitable for blueberry cultivation merely by using fertilizers at recommended rates? In order to find the solution to the previously discussed problem, the aim of the present research was to evaluate the effect of elemental sulphur and acidifying NPK fertilizers on blueberry plants grown in former arable land with a $\mathrm{pH}$ initially too high $\mathrm{pH}$ for blueberry.

\section{Material and methods}

\section{Experimental sites and plant material}

Experiments with lowbush blueberries were established in 1999 at Kärla and Vasula. Kärla (58¹9’N and $22^{\circ} 16^{\prime} \mathrm{E}$ ) is situated on the Saaremaa, island in western Estonia. The soil type in the experimental site is Umbri-Endogleyic Albeluvisol (FAO 2006), the texture is loamy sand and the plough layer is $18-25 \mathrm{~cm}$ thick. Vasula is situated in South Estonia 
in Tartu county $\left(58^{\circ} 28^{\prime} \mathrm{N}\right.$ and $\left.26^{\circ} 44^{\prime} \mathrm{E}\right)$. The soil type in the experimental area is Endoeutri-Haplic Luvisol (FAO 2006), the texture is sandy loam and the plough layer is $24-30 \mathrm{~cm}$ thick. According to agroclimatic regions of Estonia, and also taking into account several studies of microclimate, Kask (2000) has divided Estonia into different regions based on their suitability for fruit production. Kärla is situated in the coast and islands region, where winters are milder. The growing period for plants lasts fifteen days longer than in the mainland and the period free of night frosts is longer, lasting 150-180 days. At the same time May and June are dry - precipitation is half of that in the mainland for the same period. Vasula is situated in the Tartu region, where cold winters with very low temperatures (sometimes below $-37^{\circ} \mathrm{C}$, in certain areas $-39^{\circ} \mathrm{C}$ ) are typical. A vegetation period free of night frosts is short (130 days) and night frosts may be severe. In several southern places snow falls quite late and without snow cover severe frosts in November (below $-20^{\circ} \mathrm{C}$ or even more on the ground) may damage berry cultures.

Before the experiments hay was grown in Kärla and cereals in Vasula. Prior to establishing the experiment, the soil was ploughed and cultivated. Experimental plantations were established in flat area and two-year-old blueberry seedlings were used for the plantation. The space between the rows was $1 \mathrm{~m}$ and plant-to-plant spacing was $0.8 \mathrm{~m}$. The experimental design was a randomized complete block with 3 replications and 15 plants per plot. Experimental plots were not irrigated.

\section{Fertilizers and fertilization rates}

The acidifying fertilizers ammonium sulfate - $(\mathrm{NH})_{2} \mathrm{SO}_{4}(\mathrm{~N}-21 \%, \mathrm{~S}-24 \%)$, superphosphate $-\mathrm{Ca}\left(\mathrm{H}_{2} \mathrm{PO}_{4}\right)_{2}$ and $\mathrm{CaSO}_{4} \cdot 2 \mathrm{H}_{2} \mathrm{O}(\mathrm{P}-9 \%, \mathrm{~S}-12 \%)$ and potassium sulfate $-\mathrm{K}_{2} \mathrm{SO}_{4}(\mathrm{~K}-34 \%, \mathrm{~S}-18 \%)$ and elemental sulphur $(\mathrm{S} ; 100 \%)$ were used in the experiment. The quantities of the fertilizers were calculated according to the nutrient content of the soil (Table 1) and suggestions worked out by Finnish scientists Lehmushovi and Ylämäki (1999). Fertilizer application rates in the different treatments were the following:

1. In Kärla 1) control, without fertilization;

2) $25 \mathrm{~N}, 18 \mathrm{P}, 51 \mathrm{~K} \mathrm{~kg} \mathrm{ha}^{-1}$ 3) $1000 \mathrm{~S} \mathrm{~kg} \mathrm{ha}^{-1}$

4) $1000 \mathrm{~S}+25 \mathrm{~N}, 18 \mathrm{P}, 51 \mathrm{~K} \mathrm{~kg} \mathrm{ha}^{-1}$.

2. In Vasula 1) control; 2) $11 \mathrm{~N}, 15 \mathrm{P}, 34 \mathrm{~K} \mathrm{~kg}$ $\mathrm{ha}^{-1}$ 3) $1000 \mathrm{~S} \mathrm{~kg} \mathrm{ha}^{-1}$ 4) $1000 \mathrm{~S}+11 \mathrm{~N}, 15 \mathrm{P}$, $34 \mathrm{~K} \mathrm{~kg} \mathrm{ha}^{-1}$.

In both experiments elemental sulphur was applied once in the early spring of 2000. In Kärla NPK fertilizer treatments were used in the spring of 2000 and 2001. In Vasula the above-mentioned treatments were used in 2000. In 2001 only ammonium sulfate (at the rate of $25 \mathrm{~N} \mathrm{~kg} \mathrm{ha}^{-1}$ ) was applied to the NPK plots, because the potassium and phosphorus contents of the soil were high. In 2002 experimental areas were mulched using pine bark crumbs.

\section{Soil nutrient content and $\mathrm{pH}$}

Soil samples were taken prior to establishing the experiments in 1999 and in the autumns of 2001, 2002 and 2003. The samples were taken close to the plants from the soil layer to a depth of $20 \mathrm{~cm}$. Soil $\mathrm{pH}_{\mathrm{KCl}}$ was determined using an Evikon $\mathrm{pH}$ meter. The content of phosphorus (P) (ammonium lactate extractable), potassium (K) (ammonium lactate extractable), calcium $(\mathrm{Ca})$ and magnesium ( $\mathrm{Mg}$ ) (1 M ammonium acetate extract, $\mathrm{pH} 7.0$ ) was determined in 2003 (Official Methods of Analysis 1990). Organic matter concentration (\%) in soil was also analysed by loss on ignition. Three soil

Table 1. Data of soil analyses before the establishment (1999) of experimental plantations in Vasula and Kärla.

\begin{tabular}{lcccccc}
\hline Site & $\mathrm{pH}_{\mathrm{KCl}}$ & $\begin{array}{c}\text { Phosphorus } \\
\mathrm{mg} \mathrm{kg}^{-1}\end{array}$ & $\begin{array}{c}\text { Potassium } \\
\mathrm{mg} \mathrm{kg}^{-1}\end{array}$ & $\begin{array}{c}\text { Calcium } \\
\mathrm{mg} \mathrm{kg}^{-1}\end{array}$ & $\begin{array}{c}\text { Magnesium } \\
\mathrm{mg} \mathrm{kg}^{-1}\end{array}$ & $\begin{array}{c}\text { Organic mat- } \\
\text { ter \% }\end{array}$ \\
\hline Kärla & 5.5 & 17 & 53 & 1300 & 320 & 3.6 \\
Vasula & 6.2 & 168 & 194 & 2058 & 98 & 4.0 \\
\hline
\end{tabular}


samples were analysed in every variant and one sample consisted of ten subsamples.

\section{$\mathrm{N}$-Tester measurements and leaf nutrient content}

Chlorophyll content of the plants was measured using the portable Hydro N-Tester chlorophyll meter (Minolta Camera Co., Ltd. Japan). It permits rapid and non-destructive determination of leaf chlorophyll content by measuring leaf transmittance. Leaves of the same age and position on the plant were used; young leaves with non-uniform color were left aside. Chlorophyll meter readings not only respond to crop nitrogen status, but can also be affected by availability of other nutrients (Schepers et al. 1996). N-Tester readings were measured in the beginning of August 2001, 2002 and 2003.

The nutrient (nitrogen - N\%; phosphorus - $\mathrm{P} \%$; potassium - $\mathrm{K} \%$; calcium - $\mathrm{Ca} \%$; magnesium- $\mathrm{Mg} \%$ ) content in lowbush blueberry leaves was determined in the Laboratory of Plant Biotechnology at the Estonian Agricultural University. Leaf samples were collected at harvest in 2003. N concentration of air-dried samples was determined by the Kjeldahl method. The method involves the digestion of a sample in sulphuric acid using the Kjeldahl $\mathrm{Cu}$ catalyst to convert the protein nitrogen to ammonium sulphate. Ammonia is liberated by alkaline distillation using an automatic analyser Kjeltec Auto 1030. P, Ca, and $\mathrm{Mg}$ concentrations were measured by Kjeldahl digest using the flow injection analyser FIAstar 5000. Potassium concentration was determined flamephotometerically by an air-acetylene flame. Phosphorus was determined at the wavelength $720 \mathrm{~nm}$ by the Stannous Chloride method and Ca at the wavelength $570 \mathrm{~nm}$ using o-Cresolphthalein Complexone, 8-Hydroxyquinoline to mark magnesium and 2-amino-2-methyl-propanol-1 as a buffer. Magnesium was determined by Titan Yellow at the wavelength $540 \mathrm{~nm}$. All nutrient concentrations were expressed on a dry weight basis $(\% \mathrm{DW})$. Three samples in every variant were analysed and one sample consisted of leaves from ten plants.

\section{Plant yield and growth}

The first significant yield was picked on 10 Aug 2003, when the yields per blueberry plant and fruit weight were determined. At the end of the vegetation period (end of September) in 2001, 2002 and 2003 the width and height of the blueberry bushes was measured. The plant width was measured across and along the row and its average was calculated. The number of shoots (longer than $15 \mathrm{~cm}$ ) per plant was counted. Ten plants were measured in every replication.

For the determination of dry weight of blueberry roots, a soil sample was taken under the canopy of the blueberry plant with a cylindrical (6 cm diameter, $15 \mathrm{~cm}$ length) stainless steel corer. Roots were separated from the sample. After that they were washed under tap water and dried in a drying oven at a temperature of $105^{\circ} \mathrm{C}$ until constant weight was achieved. The root dry weight was calculated $\left(\mathrm{g} \mathrm{dm}^{-3}\right)$. Ten samples were taken in every replication.

\section{Statistical analysis}

The experimental results were subjected to the analysis of variance and significant differences from the control (without fertilization) were determined $(\mathrm{P}<0.05)$. To find relationships between different parameters, correlation and regression analyses were applied. The results were marked with ** (i.e. correlate significantly at the 0.01 level), * (i.e. correlate significantly at the 0.05 level) or NS (no significant correlation).

\section{Results and discussion}

\section{Soil pH and exchangeable nutrient content}

In 2001, soil $\mathrm{pH}_{\mathrm{KCl}}$ in Kärla was 4.5-5.9 and in Vasula 4.8-6.2 (Fig. 1). In the Kärla plantation, soil $\mathrm{pH}$ was lowered when $\mathrm{S}$ was applied. Using NPK fertilizer increased soil acidity in the Vasula 
plantation. In the following year, the soil was considerably more acidic in all fertilized plots compared to the control. When only elemental sulphur was used $\mathrm{pH}$ was lowered by 0.3 in Kärla and by 0.8 units in Vasula. Where NPK fertilizers were applied in conjunction with $\mathrm{S}, \mathrm{pH}$ was lowered by 1.1 and 1.5 units, respectively. In 2003 the effect of sulphur and NPK fertilizer decreased, except for NPK fertilizers at Kärla. In mentioned plantation there was no significant difference between the control and sulphur-treated plots. The application of NPK fertilizer had more effect on soil $\mathrm{pH}$. In Vasula, the soil $\mathrm{pH}$ was significantly lower when sulphur was used.
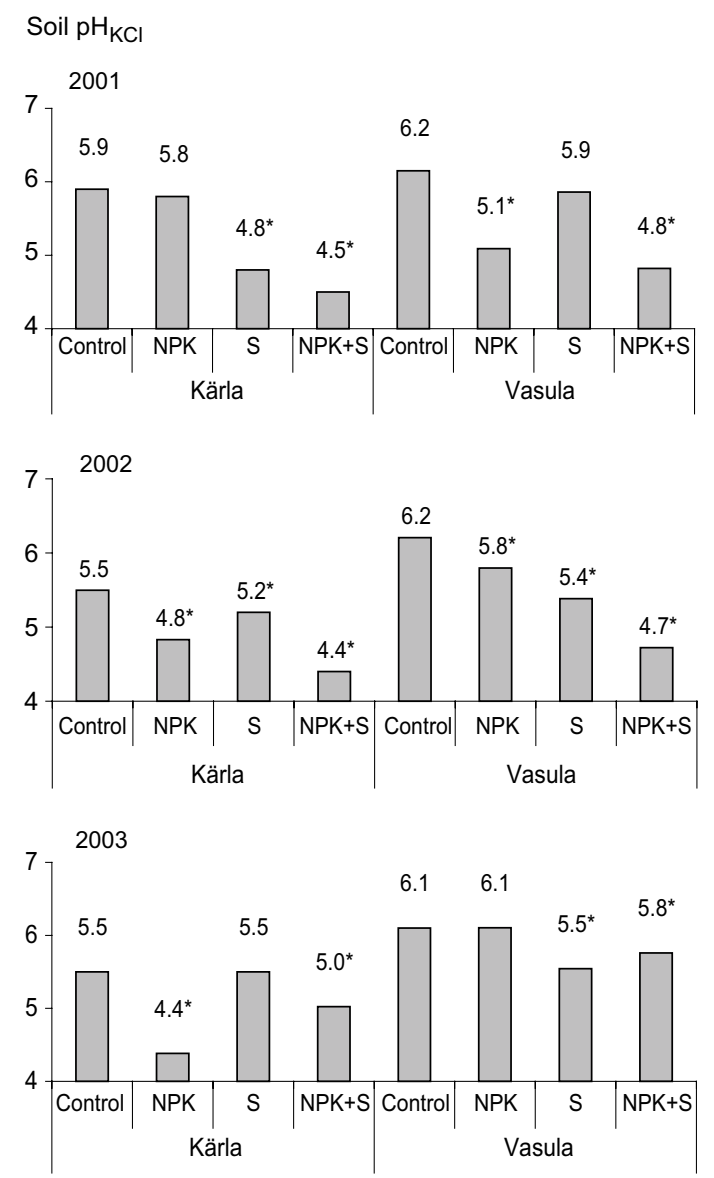

Fig. 1. Soil $\mathrm{pH}_{\mathrm{KCl}}$ values (2001, 2002 and 2003) in plots receiving different fertilization treatments. ${ }^{*}$ differences from control statistically significant at $\mathrm{P}<0.05$.
The change of soil reaction in experimental areas had a significant effect on the extracted amounts of $\mathrm{P}, \mathrm{Ca}$ and $\mathrm{Mg}$ in the soil, but there was no effect on $\mathrm{K}$ (Fig. 2). The correlation coefficients between soil $\mathrm{pH}_{\mathrm{KCl}}$ and soil $\mathrm{P}, \mathrm{Ca}$ and $\mathrm{Mg}$ were $0.52(\mathrm{P}<0.01), 0.88(\mathrm{P}<0.01)$ and $0.64(\mathrm{P}$ $<0.01)$, respectively.

The activity of soil organisms and the mobility of plant nutrients depend partly on the $\mathrm{pH}$ of soil. In most cases the application of mineral fertilizers and $\mathrm{S}$ significantly lowered soil $\mathrm{pH}$ in experimental areas. Thus, the content of plant-available macronutrients such as $\mathrm{P}, \mathrm{Ca}$ and $\mathrm{Mg}$ of the soil changed as well (Figs. 1, 2). Similar results when changing soil $\mathrm{pH}$ with sulphur have been recorded elsewhere (Haynes and Swift 1986, Owen et al. 1999). In this study, the use of recommended fertilizer rates increased soil acidity significantly (Fig. 1). In Vasula, where soil was initially less acidic, the effect of NPK fertilizers on soil pH occurred sooner than in Kärla. Sulphur significantly affected soil acidity after two years. In Kärla, the soil pH was lower and the soil texture was lighter. The influence of sulphur was clear one year after the application. The effect of NPK fertilizers was evident in 2002. To increase the effect of fertilizers an increase in fertilizer rates is often recommended. However, a larger fertilizer amount for blueberries is not advisable in the Nordic countries, since it could prolong the growing period. One-year-old shoots will not be ligneous before first frosts and the tops of shoots will be frozen. A long growing period of blueberry bushes is also one of the reasons why blueberry plants suffer from winter damage, especially young bushes during the first few years of growth. A similar problem also emerged in a half-highbush blueberry experiment with different mulches (Starast et al. 2002). At these experimental areas significant winter damage was not observed.

\section{N-Tester measurements and leaf nutrient content}

In Kärla, NPK fertilizers alone or in combination with $\mathrm{S}$ increased N-Tester reading but sulphur ap- 
Vol. 16 (2007): $34-45$

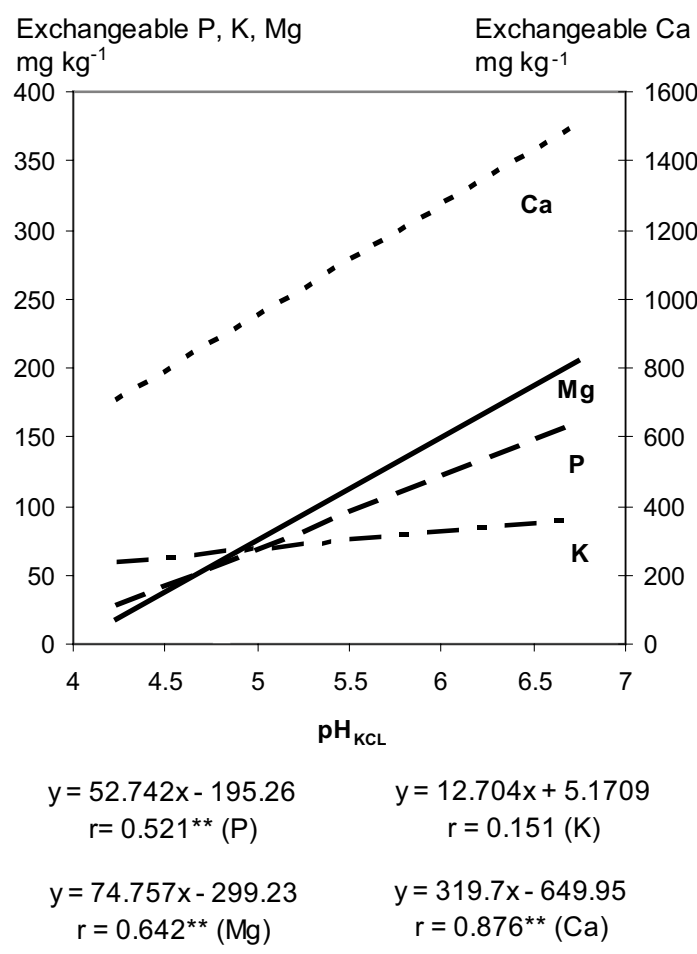

Fig. 2. Relationship between exchangeable K-, P-, Ca and $\mathrm{Mg}\left(\mathrm{mg} \mathrm{kg}^{-1}\right)$ and soil $\mathrm{pH}_{\mathrm{KCl}}$ for both experiments in 2003. ** significant $(\mathrm{P}<0.01)$ correlation.

plication alone had no effect in 2001 (Fig. 3). The opposite effect was observed at the Vasula plantation. In 2002 N-Tester readings in Kärla remained similar to 2001, while in Vasula these ranged from 326 to 459 . Significantly higher readings were recorded in Vasula in the plots where blueberry bushes were fertilized with sulphur compared to control variant. In 2003 chlorophyll meter readings in Kärla were 315-506 and in Vasula 272-391. NPK fertilizers application without $\mathrm{S}$ increased $\mathrm{N}$-Tester reading of blueberry leaves in both Kärla and Vasula. N-Tester readings were significantly influenced by the change of soil $\mathrm{pH}(\mathrm{P}<0.01)$ and were also negatively correlated with exchangeable $\mathrm{Ca}$ in the soil $(\mathrm{P}<0.01)$ (Table 2$)$.

In 2003 NPK fertilization and S application had no effect on $\mathrm{N}$ and $\mathrm{P}$ content of lowbush blueberry leaves across sites (Table 3 ). The application of NPK fertilizer and S significantly increased $\mathrm{K}$ content in Kärla but in the Vasula experiment no significant differences were noted. In Kärla S
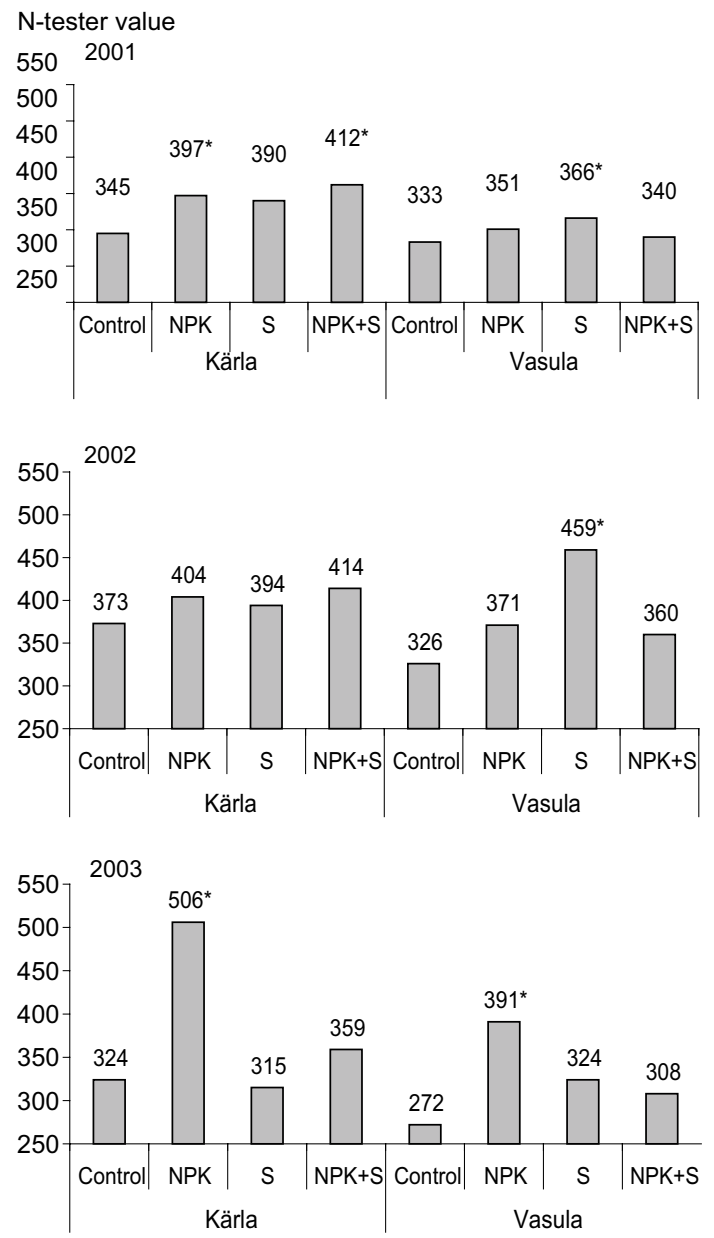

Fig. 3. N-Tester readings in lowbush blueberry plants (2001, 2002 and 2003) receiving different fertilization treatments. * differences from control statistically significant at $\mathrm{P}<0.05$.

application increased $\mathrm{Ca}$ content whereas NPK and NPK $+\mathrm{S}$ decreased Ca. In other treated plant leaves the influence of S was the opposite. In the Vasula experiment NPK $+\mathrm{S}$ fertilizers decreased $\mathrm{Ca}$ and $\mathrm{Mg}$ content in leaves. In the Kärla experiment, $\mathrm{S}$ treatment significantly increased $\mathrm{Mg}$ content.

The content of $\mathrm{N}$ and $\mathrm{P}$ was low in blueberry leaves from both experimental plantations (Table 3). The content of $\mathrm{K}$ and $\mathrm{Mg}$ was mostly sufficient (Trevett 1972). The leaf Ca content was high in Kärla while at Vasula $\mathrm{Ca}$ was within the recom- 


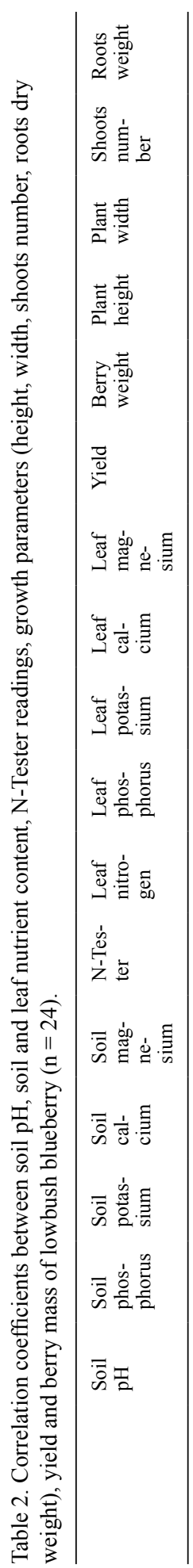

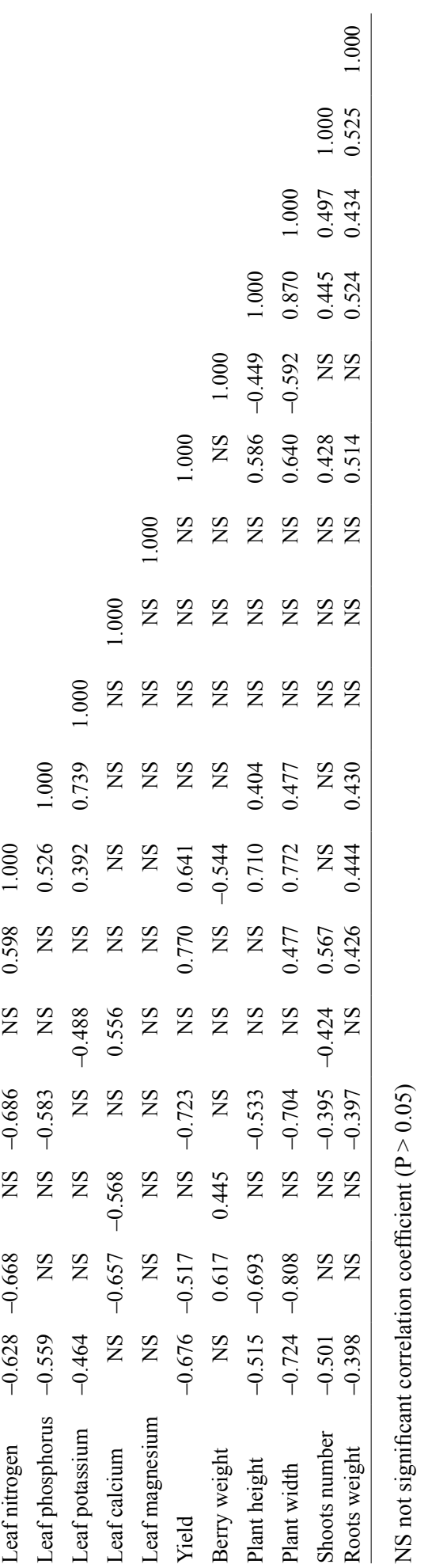


Vol. 16 (2007): 34-45

mended range. Although in Vasula the soil had higher nutrient contents than in Kärla (Table 1), the leaf nutrient contents did not show similar trend. There was a strong negative correlation between the soil $\mathrm{pH}$ and $\mathrm{N}(\mathrm{P}<0.01), \mathrm{P}(\mathrm{P}<0.01), \mathrm{K}(\mathrm{P}<$ 0.05 ) content in blueberry leaves (Table 2$)$. The leaf $\mathrm{Ca}(\mathrm{r}=-0.190, \mathrm{P}>0.05)$ and $\mathrm{Mg}(\mathrm{r}=0.221$, $\mathrm{P}>0.05$ ) contents were not significantly correlated with soil $\mathrm{pH}$ value. Nitrogen content of leaves correlated with $\mathrm{N}$-Tester readings $(\mathrm{P}<0.01), \mathrm{Ca}(\mathrm{P}$ $<0.01)$ and $\mathrm{P}(\mathrm{P}<0.01)$ content in soil. A strong relationship was noted between leaf $\mathrm{P}$ content and soil $\mathrm{Ca}(\mathrm{P}<0.01)$, leaf $\mathrm{K}$ content and soil $\mathrm{Mg}(\mathrm{P}<$ $0.05)$, leaf $\mathrm{Ca}$ and soil $\mathrm{P}(\mathrm{P}<0.01), \mathrm{K}(\mathrm{P}<0.01)$ and $\mathrm{Mg}(\mathrm{P}<0.01)$ content.

The influence of sulphur on supplementation of leaf nutrients appears two years after the application of S. Spiers and Braswell (1992) reported that sulphur increased the concentrations of leaf N, P, K and Mn. Results of this study indicated sulphur application increased $\mathrm{Mg}$ and $\mathrm{Ca}$ content of blueberry leaves in Kärla (Table 3). According to N-Tester readings NPK fertilization had an effect on N-content of blueberry leaves (Fig. 3). It can be suggested that it was caused by the increase of $\mathrm{pH}$ in soil, because a correlation between soil $\mathrm{pH}$ and
$\mathrm{N}$-Tester readings was found (Table 2). It is not known if N-Tester has been used to measure blueberry leaves before. Several experiments with other horticultural crops have indicated that fertilization increases chlorophyll meter readings (SandovalVilla et al. 1999). It has been shown that there is a strong relationship between chlorophyll meter readings and $\mathrm{N}$ content in leaves (Porro et al. 2001). The same influence and relationship was indicated in our experiment. Therefore, we can recommend $\mathrm{N}$-Tester for the evaluation of lowbush blueberry plants growing conditions.

\section{Plant growth and yield}

In 2003, in a five-year old plantation, the height of blueberry bushes was $28-35 \mathrm{~cm}$ in Kärla and $21-28 \mathrm{~cm}$ in Vasula (Fig. 4). The plant width was $59-75 \mathrm{~cm}$ in Kärla and $40-53 \mathrm{~cm}$ in Vasula. In 2001, using fertilizers and sulphur did not affect plant height in Kärla. At the same time NPK and NPK $+\mathrm{S}$ fertilizers had a significant positive influence on the plant width. In the following two years the above-mentioned treatments increased the plant height and width in the Kärla experiment. In every

Table 3. Nutrient content (\% dry matter basis) in leaves of lowbush blueberry (2003) receiving different fertilization treatments. Sufficiency levels of nutrients in leaves of lowbush blueberry from Trevett (1972).

\begin{tabular}{llccccc}
\hline Site & Variant & $\begin{array}{c}\text { Nitrogen } \\
\%\end{array}$ & $\begin{array}{c}\text { Phosphorus } \\
\%\end{array}$ & $\begin{array}{c}\text { Potassium } \\
\%\end{array}$ & $\begin{array}{c}\text { Calcium } \\
\%\end{array}$ & $\begin{array}{c}\text { Magnesium } \\
\%\end{array}$ \\
\hline \multirow{2}{*}{ Kärla } & Control & 1.34 & 0.06 & 0.47 & 0.56 & 0.13 \\
& NPK & 1.50 & 0.06 & 0.55 & $0.53^{*}$ & 0.12 \\
& Sulphur (S) & 1.36 & 0.04 & 0.40 & $0.64^{*}$ & $0.17^{*}$ \\
& NPK + S & 1.43 & 0.06 & $0.57^{*}$ & $0.50^{*}$ & $0.15^{*}$ \\
& Control & 1.17 & 0.04 & 0.49 & 0.45 & 0.13 \\
& NPK & 1.21 & 0.05 & 0.52 & 0.41 & 0.12 \\
& Sulphur & 1.14 & 0.04 & 0.48 & 0.41 & 0.12 \\
& NPK + S & 1.20 & 0.05 & 0.49 & $0.35^{*}$ & $0.11^{*}$ \\
& Sufficiency level & $1.60-2.38$ & $0.12-0.22$ & $0.40-0.90$ & $0.27-0.52$ & $0.12-0.25$ \\
& (Trevett 1972) & & & & & \\
\hline
\end{tabular}

\footnotetext{
$*$ differences from control statistically significant at $\mathrm{P}<0.05$.
} 
study-year the application of fertilizers and S significantly increased plant sizes in Vasula. A negative correlation was found with P-content of the soil and plant height and width $(\mathrm{P}<0.01)$ (Table 2).

The growth of shoots was different in the two experimental sites - in Kärla, the number of long shoots remained between 3 and 23 and only 2-17 in Vasula (Fig. 5). In Kärla, shoots grew better with the application of NPK and NPK + S fertilisers all years, and the number of shoots was more than doubled compared to control. Compared to the unfertilized bushes, the growth of shoots was not influenced when S was applied. In Vasula, in 2001, $\mathrm{S}$ application significantly affected the growth of shoots. The next year shoot development was poor and plants had only 4-6 shoots. In 2003, fertilization and $\mathrm{S}$ application increased the number of shoots. On average, the growth of shoots was better in Kärla compared to Vasula. The number of shoots correlated negatively with $\mathrm{Mg}$ content and $\mathrm{pH}$ of soil $(\mathrm{P}<0.01)$ (Table 2$)$.

In 2003, the dry weight of blueberry roots in Kärla was significantly higher in NPK-plots than in control. In Vasula NPK fertilizers with sulphur increased the root weight, while sulphur or fertilizers alone had not significant effect.

The vegetative growth of blueberry bushes depended significantly on soil reaction and exchangeable $\mathrm{Ca}$ and $\mathrm{P}$ content in soil (Table 2). There was a positive correlation with $\mathrm{N}$ and $\mathrm{P}$ content of leaf (barring shoot number) and NTester reading (barring plant height).

The yield per bush was greatly variable and the yield in Kärla was higher than in Vasula (Fig. 6).

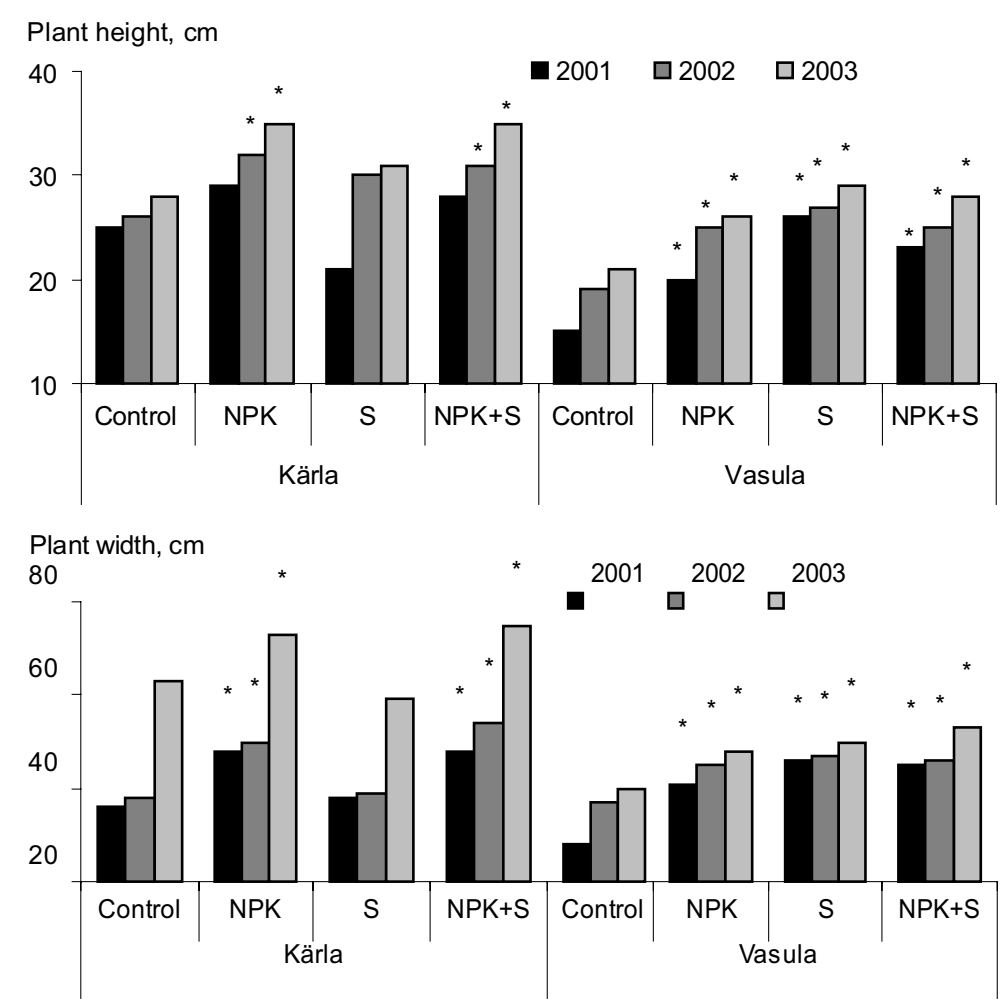

Fig. 4. Height $(\mathrm{cm})$ and width $(\mathrm{cm})$ of lowbush blueberry plants (2001, 2002 and 2003) receiving different fertilization treatments. * differences from control statistically significant at $\mathrm{P}<0.05$. 
Vol. 16 (2007): 34-45

A significant positive influence of NPK fertilization on yield was found in both Kärla and Vasula, and yield were $336 \mathrm{~g}$ and $41 \mathrm{~g}$ higher compared to the control, respectively. The change in soil $\mathrm{pH}$ caused by fertilization had a significant influence on the yield per plant $(\mathrm{P}<0.01)$ (Table 2). The yield showed a negative correlation with $\mathrm{P}$ and $\mathrm{Ca}$ content of soil $(\mathrm{P}<0.01)$ and a positive relationship with $\mathrm{N}$-Tester reading and $\mathrm{N}$ content in leaves $(\mathrm{P}<0.01)$. When blueberry plants had better growth, the yield was higher too.
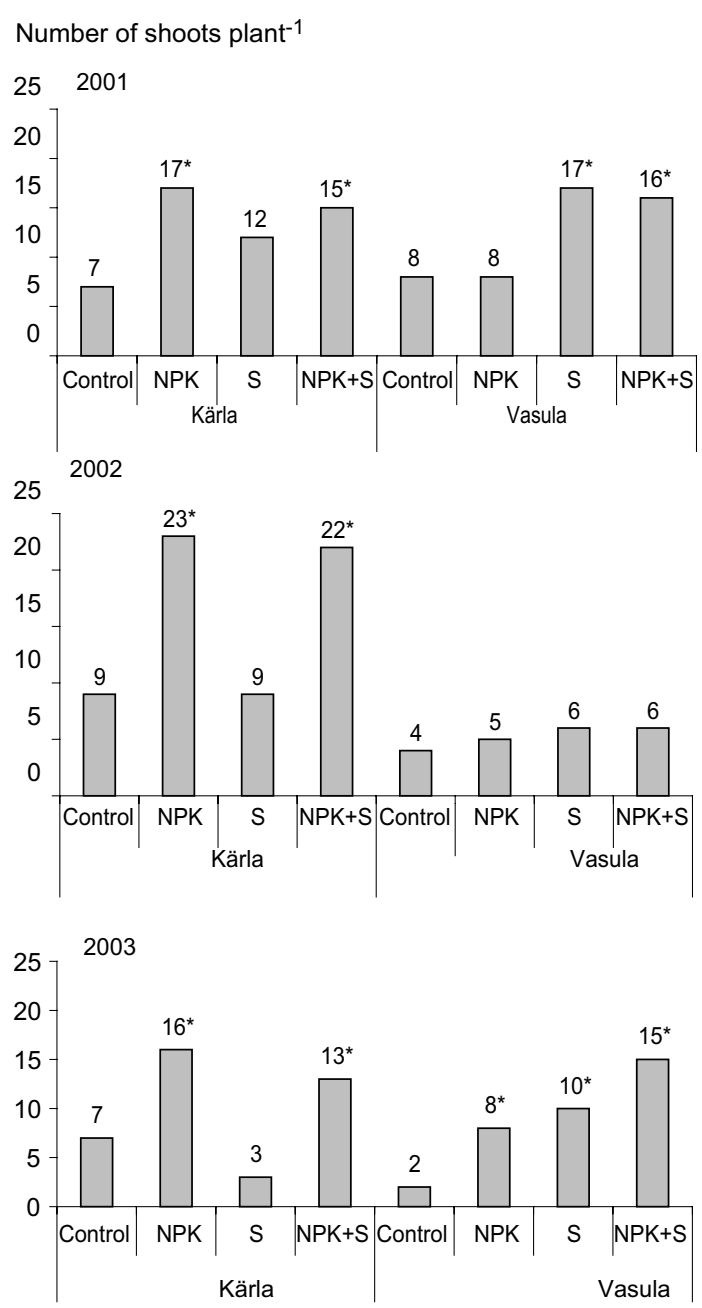

Fig. 5. Number of shoots of lowbush blueberry plants (2001, 2002 and 2003) receiving different fertilization treatments. $*$ differences from control statistically significant at $\mathrm{P}<0.05$.
The effect of fertilization on berry weight was not significant in either experimental site (Fig. 6). Berry weight correlated negatively with leaf $\mathrm{N}$ content $(\mathrm{P}<0.01)$ and positively with soil $\mathrm{P}$ and $\mathrm{K}$ content $(\mathrm{P}<0.01)$ (Table 2$)$. The soil $\mathrm{pH}$ did not have a significant effect. However, higher and larger bushes had smaller berries $(\mathrm{P}<0.05)$.

It is known that soil reaction plays an important role in blueberry cultivation. Blueberries need acidic soil for optimal growth (Hall et al. 1964, Spiers 1984). On the other hand, in the case of too acidic soil $(\mathrm{pH}<3.5)$ plant growth and yield have been reduced greatly (Spiers 1984). Experiments have also shown that blueberry cultivars differ in tolerance to alkaline growing conditions (Austin and Bondari 1992, Finn et al. 1993). At lower $\mathrm{pH}$ values the growth was improved by adding phosphorus (Holmes 1960). The soil reaction in our experiments in Kärla was pH 5.5. In Vasula, the soil was less acidic (Table 1). The experiments with sulphur and NPK fertilizers showed that the soil reaction could be lowered by 1.1 and 1.5 units respectively (Fig. 1). It was also found that the lowering of soil $\mathrm{pH}$ and fertilization promoted growth, which in turn increased the yield of the first production year (Figs. 4-6). It may be suggested that the lowering of soil $\mathrm{pH}$ made nutrients more available for blueberries. The predominance of $\mathrm{NH}_{4}$ in the soil at low $\mathrm{pH}$ may be an important factor contributing to the preference of blueberries to acid soil, since they are known to prefer $\mathrm{NH}_{4}$ to $\mathrm{NO}_{3}$ as their major source of $\mathrm{N}$ (Korcak 1988). Presumably uptake of micronutrients was also improved, because soil acidification caused by the addition of S resulted in increases of extractable Mn and Fe levels (Haynes and Swift 1986). At the same time, Spiers and Braswell (1992) have explained that using only acidic fertilizers was not enough to achieve the desired $\mathrm{pH}$ of the soil. Nutrient uptake of blueberry plants is significantly influenced by the fact that blueberry plants live in symbiosis with mycorrhizal fungi, which support nutrient uptake, especially $\mathrm{N}$ and $\mathrm{P}$, from soil (Read and Stribley 1973). The fungi produce extracellular enzymes that break down organic matter, enabling the plant to assimilate nutrients mineralized from organic compounds present in 
Starast, M. et al. Fertilization of lowbush blueberry

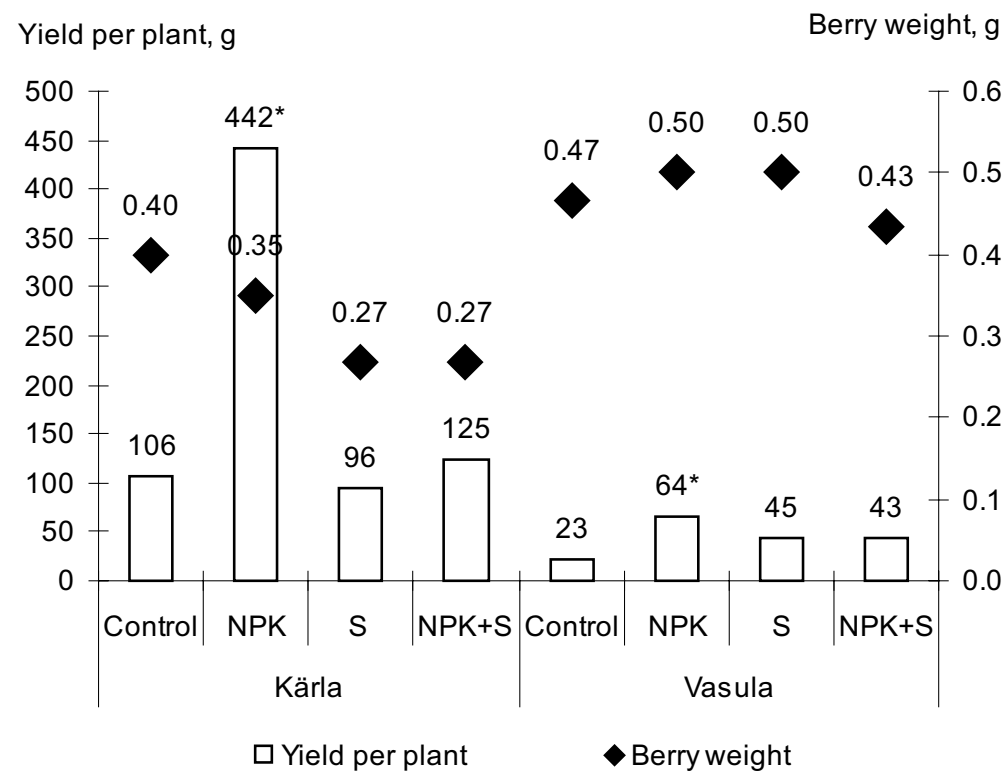

Fig. 6. Yield (g) and berry weight (g) of lowbush blueberry (2003) receiving different fertilization treatments. $*$ differences from control statistically significant at $\mathrm{P}<0.05$.

the colloidal material surrounding roots (Perotto et al. 1995).

A blueberry plantation yields within three to four years after establishment. To ensure high yields later on, it is important to create optimal conditions for vegetative growth during the first years. The quantity of blueberry yield depends on soil acidity (Spiers 1984, Austin and Bondari 1992). According to the review by Vander Kloet (1988), lowbush blueberry seed-grown plants grow slowly during the first year and are also more susceptible to the influences of environment than vegetatively propagated plants. The rhizosystem of seed-grown plants develops slower than it does in the case of vegetative propagation (Morrison et al. 2000). Fertilizers used in our experiment influenced soil $\mathrm{pH}$ and a correlation with yield was also found (Table 2). The highest yield of the two experimental locations was obtained in Kärla from a plot where soil $\mathrm{pH}_{\mathrm{KCl}}$ was 4.4 (Fig. 6). In the Vasula experiment the yield of fertilized plants was higher than that of control plants, but compared to Kärla the yield was modest. However, $\mathrm{pH}$ was not the only factor, because in one fertilized plot in Vasula the soil acidity was higher, but the yield was still very low. We may suppose the soil texture might have influenced the results, because it was different in the two experimental sites. In soil with light texture, the roots of fertilized plants were larger and $\mathrm{N}$-content of the leaves was also higher (Table 3). It can be presumed that besides soil conditions the results of the experiment were influenced by different climatic conditions. For instance, flower bud development and the number of flowers produced by a blueberry plant depend significantly on soil moisture (Benoit et al. 1984). It can be suggested that a longer vegetation period in Saaremaa compared to Tartu region promoted development of plants after planting and thus later influenced productivity.

It can be concluded that the amount of fertilizers recommended for cultivating Vaccinium species was also sufficient to lower soil $\mathrm{pH}$ to a level suitable for good growth and yield of lowbush blueberry. Soil acidity increased when elemental sulphur was used, but on loamy sand soil with light texture this treatment does not increase plant productivity. The influence of sulphur on soil $\mathrm{pH}$ 
Vol. 16 (2007): 34-45

began to decrease four years after application. However, on soil with light texture it is affected earlier. Sulphur can be recommended for use in nutrient rich soil to increase soil acidity, but not for nutrient poor soil with light texture, where using only NPK fertilizers are more effective.

Acknowledgements. The present research was carried out as a part of the project "Developing commercial wild berry industry in Estonia" between Estonia and Canada. We would like to express our thanks to Prof. Dave Percival and other colleagues at the Nova Scotia Agricultural College for their invaluable help in this investigation. This research was financially supported by the Estonian Science Foundation.

\section{References}

AOAC 1990. Official methods of analysis 15th ed. Association of Official Analytical Chemists, Arlington, Virginia. Modified. $1230 \mathrm{p}$.

Austin, M.E. \& Bondari, K. 1992. Hydrogel as a field medium amendment for blueberry plants. HortScience 27: 973-974.

Benoit, G.R., Grant, W.J., Ismail, A.A. \& Yarborough, D.E. 1984. Effect of soil moisture and fertilizer on the potential and actual yield of lowbush blueberries. Canadian Journal of Plant Science 64: 683-689.

Brown, J.C. \& Draper, A.D. 1980. Differential response of blueberry (Vaccinium) progenies to $\mathrm{pH}$ and subsequent use of iron. Journal of the American Society for Horticultural Science 105: 20-24.

Clark, J.R. \& Moore, J.N. 1991. Southern blueberry response to mulch. Hort Technology 1: 52-54.

FAO 2006. World reference base for soil resources. World Soil Resources Report 103. FAO, Rome. 145 p.

Finn, C.E., Luby, J.J., Rosen, C.J. \& Ascher, P.D. 1993. Blueberry germplasm screening at several soil $\mathrm{pH}$ regimes. I. Plant survival and growth. Journal of the American Society for Horticultural Science 118: 377-382.

Gagnon, B., Simard, R.R., Lalande, R. \& Lafond, J. 2003. Improvement of soil properties and fruit yield of native lowbush blueberry by papermill sludge addition. Canadian Journal of Soil Science 83: 1-9.

Gustavsson, B.A. 1999. Effects of mulching on fruit yield, accumulated plant growth and fungal attack in cultivated lingonberry, cv. Sanna, Vaccinium vitis-idaea L. Gartenbauwissenschaft 64: 65-69.

Hall, I.V., Aalders, L.E. \& Townsend, L.R. 1964. The effects of pH on the mineral composition and growth of the lowbush blueberry. Canadian Journal of Plant Science 44: 433-438.

Haynes, R.J. \& Swift, R.S. 1986. Effect of soil amendments and sawdust mulching on growth, yield and leaf nutrient content of highbush blueberry plants. Scientia Horticulturae 29: 229-238.

Holmes, R.C. 1960. Effect of phosphorus and $\mathrm{pH}$ on iron chlorosis of the blueberry in water culture. Soil Science 90: 374-379.

Kask, K. 2000. Eesti kliima ja puuviljandus. In: Eskla, V. (ed.). Aiapidaja aastaraamat Aiatark 2000. Tallinn, Maalehe Raamat. p. 62-66. (in Estonian).
Korcak, R.F. 1988. Nutrition of blueberry and other calcifuges. Horticultural Reviews 10: 183-227.

Lehmushovi, A. \& Ylämäki, A. 1999. Pensasmustikkaakin on osattava viljellä. Puutarha \& Kauppa 11: 6-7. (in Finnish).

Morrison, S., Smagula, J.M. \& Litten, W. 2000. Morphology, growth, and rhizome development of Vaccinium angustifolium Ait. seedlings, rooted softwood cuttings, and micropropagated plantlets. HortScience 35, 4: 738-741.

Nesmith, D.S. 2003. Survival and vigor of southern highbush blueberry genotypes with and without pine bark mulch. Small Fruits Review 2: 81-86.

Owen, K.M., Marrs, R.H., Snow, C.S.R. \& Evans, C.E. 1999. Soil acidification - the use of sulphur and acidic plant materials to acidify arable soils for the recreation of heathland and acidic grassland at Mismere, UK. Biological Conservation 87: 105-121.

Perotto, S., Peretto, R., Faccio, A., Schubert, A., Varma, A. \& Bonfante, P. 1995. Ericoid mycorrhizal fungi: cellular and molecular bases of their interactions with host plant. Canadian Journal of Botany 73: 557-568.

Porro, D., Dorigatti, C., Stefanini, M. \& Ceschini, A. 2001. Use of SPAD Meter in diagnosis of nutritional status in apple and grapevine. Acta Horticulturae 564: 243-252.

Read, D.J. \& Stribley, D.P. 1973. Effect of mycorrhizal infection on nitrogen and phosphorus nutrition of Ericaceous plants. Nature: New Biology 244: 81-82.

Sanderson, K.R., Carter, M.R. \& Ivany, J.A. 1996. Effects of gypsum on yield and nutrient status of native lowbush blueberry. Canadian Journal of Plant Science 76: 361-366.

Sandoval-Villa, M., Wood, C.W. \& Guertal, E.A. 1999. Ammonium concentration in solution affects chlorophyll meter readings in tomato leaves. Journal of Plant Nutrition 22, 11: 1717-1729.

Schepers, J.S., Blackmer, T.M., Wilhelm, W.W. \& Resende, M. 1996. Transmittance and reflectance measurements of corn leaves from plants with different nitrogen and water supply. Journal of Plant Physiology 148: 523-529.

Smolarz, K. \& Mercik, S. 1989. Growth and yield of highbush blueberry cv. Bluecrop (Vaccinium corymbosum L.) in relation to the level of nitrogen fertilization. Acta Horticulturae 241: 171-174.

Spiers, J.M. 1984. Influence of lime and sulfur soil additions on growth, yield, and leaf nutrient content of rabbiteye blueberry. Journal of the American Society for Horticultural Science 109, 4: 559-562.

Spiers, J.M. 1998. Establishment and early growth and yield of 'Gulfcoast' southern highbush blueberry. HortScience 33: 1138-1140.

Spiers, J.M. \& Braswell, J.H. 1992. Soil-applied sulfur affects elemental leaf content and growth of 'Tiflblue' rabbiteye blueberry. Journal of the American Society for Horticultural Science 117, 2: 230-233.

Starast, M., Karp, K. \& Paal, T. 2002. The effect of using different mulches and growth substrates on half-highbush blueberry (Vaccinium corymbosum $\times$ V. angustifolium) cultivars Northblue and Northcountry. Acta Horticulturae 574: 281-286.

Strømeng, G.M. \& Stensvand, A. 2001. Susceptibility of highbush blueberry (Vaccinium corymbosum L.) cultivars to Godronia canker (Godronia cassandrae f. sp. vaccinii) in Norway. Gartenbauwissenschaft 66: 78-84.

Trehane, J. 2004. Blueberries, cranberries and other Vacciniums. Royal Horticultural Society, Timber Press, Portland, Cambridge. 256 p.

Trevett, M.F. 1972. A second approximation of leaf analysis standards for lowbush blueberries. Research in the life sciences. Maine Agricultural Experimental Station Bulletin 19, 5: 15-16.

Vander Kloet, S.P. 1988. The genus Vaccinium in North America. Canadian Government Publishing Centre, Ottawa, Canada. $201 \mathrm{p}$. 